\title{
Albumin Metabolism: Effect of the Nutritional State and the Dietary Protein Intake
}

\author{
W. P. T. James and A. M. HAY \\ From the Gastrointestinal Research Unit, Massachusetts General Hospital, \\ Boston, Massachusetts 02114; and the Tropical Metabolism Research Unit, \\ University of the West Indies, Kingston, Jamaica
}

A в S T R A C T Nine malnourished and nine children who had recovered from malnutrition were given a single injection of albumin- ${ }^{131} \mathrm{I}$ and were studied during consecutive periods in which the dietary protein was changed.

Malnourished children had significantly lower catabolic rates of albumin than had recovered children on the same protein intake. Both nutritional groups, however, showed a progressive fall in catabolic rate after 3-5 days on a low protein diet $(0.7-1.0 \mathrm{~g} / \mathrm{kg}$ per day), and the maximum effect was seen in the 2 nd wk of low protein feeding. The catabolic rate could return to normal within $3 \mathrm{wk}$ in a malnourished child fed $4 \mathrm{~g}$ of protein $/ \mathrm{kg}$ per day.

The albumin synthetic rate was measured by a computer technique suitable for nonsteady-state conditions. The synthetic rate in the malnourished groups (101 $\mathrm{mg} / \mathrm{kg}$ per day) fed on a low protein diet was significantly lower than the rate in the recovered groups (148 $\mathrm{mg} / \mathrm{kg}$ per day). The synthetic rate responded rapidly to a change in diet; when the rate fell, the intravascular albumin mass was maintained by two compensating mechanisms: (1) a net transfer of extravascular albumin into the intravascular pool ; and (2) by a delayed fall in the catabolic rate. The net transfer of albumin into the intravascular compartment diminished as the catabolic rate fell.

Adaptation to a low protein diet was associated with: $(a)$ low synthetic and catabolic rates of albumin ; $(b)$ a reduced extravascular albumin mass;

Received for publication 7 March 1968 and in revised form 8 May 1968. and $(c)$ a capacity for a rapid return to normal in the synthetic rate when the dietary protein was increased.

\section{INTRODUCTION}

Animal and human studies of albumin metabolism in protein depletion have been concerned largely with the assessment of the catabolic rate of albumin and the extent to which it changes in the depleted subject or animal (1-5).

These studies have shown that a reduction in the rate of albumin degradation does occur in protein depletion, but it is still not clear whether this reduction is related to the nutritional state of the body, or to the level of the dietary protein intake, or to both (6).

In steady-state conditions the synthetic rate, by definition, is equal to the catabolic rate. When there is not a steady state, an indirect computer analysis developed by Matthews $(7,8)$ was used to distinguish between synthesis and transfer of albumin between albumin pools.

The present study was designed to estimate both the catabolic and synthetic rates of albumin in malnourished and recovered children, during consecutive periods of feeding at different levels of protein intake. A whole body counter permitted the accurate measurement of the total retained activity of albumin-131 I over a period of 1 month, and a computer analysis, suitable for nonsteadystate conditions, was used to estimate the synthetic rate of albumin. 


\section{METHODS}

\section{Patients}

18 investigations were performed on 15 male Jamaican children admitted to a metabolic ward with proteincalorie malnutrition. Nine malnourished children were studied, three of whom were included in the nine children investigated after recovery. Six of the nine malnourished children were diagnosed as marasmic and three as marasmic kwashiorkor.

On admission children were treated with graduated milk feeds, oral iron, folic acid, multiple vitamin mixture, and potassium chloride. Intravenous fluids were given on rare occasions when necessary. No child with an infection or worm infestation on admission was included in the study. Studies were begun on the malnourished children 2-10 days after admission when they were free of edema and able to tolerate a milk mixture containing $120 \mathrm{kcal}$ and $2 \mathrm{~g}$ of protein $/ \mathrm{kg}$ per day.

The recovered children were studied after they had been in the ward for at least 2 months and were approaching the 50th percentile figure for the weight of North American children of the same height (9).

\section{Design of study}

At least 1 day before injection of iodinated human albumin, all children were given Lugol's iodine twice daily, and this was continued throughout the study to prevent the uptake of radioactive iodine by the thyroid.

Three dietary phases were used in each study. In the 1st phase, all children had a 10 day period on a high protein diet containing $2.0-4.8 \mathrm{~g}$ of milk protein $/ \mathrm{kg}$ per day. In the 2 nd phase, lasting 7 days, all children were given a low protein diet containing $0.7-1.0 \mathrm{~g}$ of milk protein $/ \mathrm{kg}$ per day. In the 3rd phase, which lasted 1 week, four recovered children continued on the low protein diet (group A), and five reverted to a high protein diet (group B). Similarly, four malnourished children (group $C$ ) received a low protein diet in phase 3 and the other five children a high protein diet (group D). Table I lists the mean intakes of each group in each phase. The low level of protein intake is adequate for maintaining nitrogen balance, but not for growth (10). All children were given an isocaloric diet throughout the study except subjects P. W. and M. M., who received an increase in calories in the 2 nd and 3 rd phases.

$10 \mathrm{~min}$ after the intravenous injection of ${ }^{131}$ I-labeled albumin a venous sample was taken and the plasma volume was estimated by the isotope dilution method. Four blood samples were taken on the 1st day, three on the second, and two on the 3rd day. Daily venous samples were then obtained, except at the end of each phase when a further plasma volume determination was made with Evans blue.

Urine was collected on the 1st day, and subsequently for 5 days in each phase. All urine collections lasted approximately $24 \mathrm{hr}$ and were accurately timed for conversion to 24-hr excretion rates. Stools were collected in phase 1 from the first three subjects, but as the activity was less than $1 \%$ of the urine activity, stools were not collected in subsequent cases.

\section{Measurement of radioactivity}

The amount of radioactivity administered was measured as follows. Approximately $1 \mathrm{ml}$ of albumin- ${ }^{181} \mathrm{I}$ solution containing $10 \mu \mathrm{c} / \mathrm{ml}$ was taken up in a weighed syringe that was reweighed to find the weight of solution for injection. The solution was injected into the external jugular vein and the syringe was rinsed. The activity in the washings was counted; the weight of albumin remaining in the syringe was calculated by reference to a standard that contained a known weight and activity of the injection solution. The dose received was found by subtracting the weight of residual albumin solution from the initial weight of solution in the syringe.

Activity in the child and in urine samples was measured in a $4 \pi$ liquid scintillation whole body counter, 1 previously described by Garrow (11). The child was carefully positioned in the counter and was counted at least once daily. Whole body counts were corrected for selfabsorption and geometry, as described below. A channel width was selected for ${ }^{181} \mathrm{I}$ assay which produced negligible counts due to the ${ }^{0} \mathrm{~K}$ content of the child.

Urine was made up to the same volume as a standard solution in an identical container. The standard was used for both urine and whole body counting. No correction for geometry was therefore necessary with the urine collections.

In phases 1 and $2,0.5 \mathrm{ml}$ of serum and in phase $3,1.0$ $\mathrm{ml}$ of serum was counted to a statistical accuracy of $1 \%$ in a well counter. A standard prepared from the injection solution was also counted.

\section{Preparation of albumin}

Human albumin 2 was iodinated with thiosulfate-free ${ }^{131}$ I by McFarlane's monochloride technique $(12,13)$. A preoxidation step was used for all iodinations, and a minimum efficiency of labeling of $65 \%$ was obtained. Unbound ${ }^{131} \mathrm{I}$ was removed by passage of the mixture through an anion exchange column of Deacidite. ${ }^{3}$ Before use, it was established that more than $98 \%$ of the activity in each preparation was precipitated with $10 \%$ trichloroacetic acid. After iodination, sufficient Lister human albumin 4 was added to reduce the specific activity of the iodinated albumin solution to less than $1 \mu \mathrm{c} / \mathrm{mg}$ of albumin, and to minimize radiation damage (14). The solution was then sterilized by passage through a Seitz filter.

Separate investigations in adults showed that preparations had the same half-life and fractional catabolic rate

1 Packard model 5107 liquid scintillator radioactivity counter, Packard Instrument Co., Inc., Downers Grove, III.

2 Behringwerke A. H., Marburg-Lahn, W. Germany.

3 Deacidite FF, Chloride form 100-200 mesh, The Permutit Company, Ltd., London, W.4.

4 Lister Institute, Herts, England. 
TABLE I

Average Protein and Calorie Intakes of Four Groups of Children during Three Phases

\begin{tabular}{cccccc}
\hline Group & $\begin{array}{c}\text { No. in } \\
\text { each } \\
\text { group }\end{array}$ & $\begin{array}{c}\text { Nutritional } \\
\text { state }\end{array}$ & Phase & $\begin{array}{c}\text { Cal- } \\
\text { ories }\end{array}$ & $\begin{array}{c}\text { Pro- } \\
\text { tein }\end{array}$ \\
\hline & & & & kcal $/ \mathrm{kg}$ & $\mathrm{g} / \mathrm{kg}$ \\
per day & per day \\
A & 4 & Recovered & 1 & 133 & 3.3 \\
& & & 2 & 129 & 0.74 \\
& & & 3 & 129 & 0.74 \\
B & 5 & Recovered & 1 & 140 & 3.4 \\
& & & 2 & 132 & 0.73 \\
& & & 3 & 137 & 3.3 \\
C & 4 & Malnourished & 1 & 119 & 3.7 \\
& & & 2 & 119 & 0.76 \\
& & & 3 & 121 & 0.79 \\
D & 5 & Malnourished & 1 & 159 & 4.8 \\
& & & 2 & 168 & 1.0 \\
& & & 3 & 176 & 5.6 \\
\hline
\end{tabular}

Intakes of protein and calories are related to the average body weight in each phase.

as ${ }^{120}$ I-labeled albumin prepared independently by the International Atomic Energy Agency. In these studies, less than $5 \%$ of the dose was excreted in the urine in the 1 st $24 \mathrm{hr}$. Malnourished children injected with each preparation also excreted less than $5 \%$ of the activity in the first day. In the recovered children who had a faster catabolic rate than adults $(2,15)$, up to $7 \%$ of the dose was excreted in the 1st day.

\section{Chemical methods}

Serum globulins were precipitated with $10 \%$ trichloroacetic acid in ethanol (16), and the protein content of the supernatant containing albumin was measured in duplicate by the colorimetric method of Lowry, Rosebrough, Farr, and Randall (17).

Urine collections were checked for any losses by measuring the 24-hr creatinine excretion rates for the individual child. Urinary creatinine was measured by the method of Bonsnes and Taussky (18).

Evans blue in serum was measured in duplicate on $0.5 \mathrm{ml}$ serum by Constable's precipitation method (19). When plasma volume was estimated simultaneously with albumin ${ }^{-181} \mathrm{I}$ and Evans blue, the results agreed to within $\pm 2 \%$, as was found by Leonard, Banwell, and Craggs (20).

\section{Calculations}

Most of the calculations were made on an IBM 1620 digital computer.

Values for whole body, serum, urine, background, and standard counts, together with plasma volume and serum albumin results, were used in a program designed to carry out the following calculations.

(1) Whole body activity was expressed as a percentage of the dose received. The logarithms of these values plotted against time were fitted with the best straight line by the method of least squares. The whole body activity curve was curvilinear in the 1 st 3 days before the extravascular activity had reached a peak. Before this had occurred, most of the albumin ${ }^{121}$ I was in the intravascular compartment and more albumin ${ }^{-181} I$ was therefore catabolized. During the redistribution of albumin- ${ }^{181}$ I the self-absorption of ${ }^{131} \mathrm{I}$ counts by the child was also changing. For these reasons, values obtained within the 1st 3 days were excluded before calculating least squares lines. The intercept of the whole body least squares line was arbitrarily corrected to $100 \%$ dose, and the correction factor, so obtained, was then applied to the whole body least squares line for phases 2 and 3 . This corrected for differences in self-absorption and geometry between the child and the standard.

(2) Daily values for plasma volume were calculated by interpolation from measurements made at the beginning and end of each phase. The daily total intravascular masses and activities were then obtained. Total extravascular activity was found by subtracting the total intravascular activity from the corrected whole body activity least squares line. Values for total intra- and extravascular activity were then fitted with the best straight line by the method of least squares.

(3) Daily urine activities converted to 24-hr excretion activities were expressed as a percentage of the total intravascular activity that existed at the midpoint in time of each urine collection to give the daily fractional catabolic rate. This was multiplied by the intravascular albumin mass to give the daily absolute catabolic rate in $g$ of albumin per day.

After these computer calculations, the absolute catabolic rate in $\mathrm{mg} / \mathrm{kg}$ per day was calculated by dividing the daily absolute catabolic rate $(\mathrm{g} / \mathrm{day})$ by the child's weight on the same day. The daily values for the fractional and absolute catabolic rates in all the children were used for an analysis of variance. The statistical significance of the catabolic rate changes in different phases was tested, as was the difference between groups of children in each dietary phase (21).

A separate computer program was used to estimate the fractional synthetic rate (see below). The absolute synthetic rate was then calculated by multiplying the fractional synthetic rate by the mean of the total intravascular mass for the phase and dividing this figure by the mean of the daily body weights for the phase. The absolute synthetic rate values were grouped and analyzed for statistically significant differences.

\section{Calculation of the albumin synthetic rate}

The albumin synthetic rate was estimated by a curvefitting procedure. A computer was used to generate curves for the total activity in both the intra- and extravascular compartments as a function of time. Summation of the intra- and extravascular curves yielded the whole body activity curve. By adjustment of the appropriate rate coefficients, the shape of the generated curves could be modified until a close fit to the experimental curves was obtained. 
The curves were generated according to a simplified model of albumin metabolism (see Fig. 1), the same as that employed by Matthews (8) for analysis with a functional analogue computer. This model assumes that there is a single extravascular pool, that synthesis and catabolism occur in relation to the intravascular pool, and that the intravascular albumin mass remains constant.

The model may be described by the following equations.

$$
\begin{aligned}
\frac{\mathrm{d} X_{1}}{\mathrm{~d} t} & =K_{31} X_{3}-\left(K_{12}+K_{13}\right) X_{1} \\
\frac{\mathrm{d} X_{3}}{\mathrm{~d} t} & =K_{13} X_{1}-K_{31} X_{3} \\
\frac{\mathrm{d} M_{1}}{\mathrm{~d} t} & =m_{01}+m_{31}-m_{12}-m_{13} .
\end{aligned}
$$

Since the intravascular albumin mass is assumed to remain constant, $\mathrm{d} M_{1} / \mathrm{d} t=0$, and

$$
m_{01}-m_{12}=m_{18}-m_{31} .
$$

The term $m_{01}-m_{12}$ represents the difference between synthetic and catabolic rates, or the net transfer of albumin from pool 1 to pool 3. If there is a net transfer of albumin, whether positive or negative, from pool 1 to pool 3 , then the quantity $M_{8}$ must change with time.

$$
\left(M_{3}\right)_{t}=\left(M_{3}\right)_{0}+\left(m_{01}-m_{12}\right)
$$

and hence,

$$
\left(K_{31}\right)_{t}=m_{31} /\left(M_{3}\right)_{t} .
$$

Under steady-state conditions, the rate coefficients in equations 1 and 2 are constant, and these two simultaneous differential equations may be solved by analytical methods. Under the present experimental conditions,

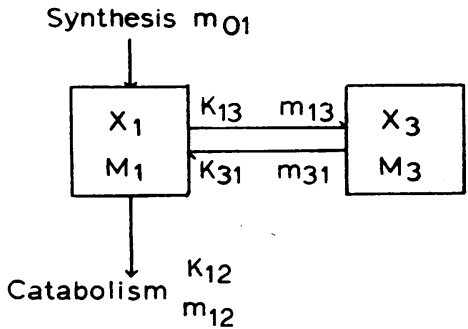

$$
\begin{aligned}
\text { Pool } 1 \text { Intravascular Albumin } \\
\text { Pool } 3 \text { Extravascular Albumin } \\
X=\text { Total activity in each pool } \\
M=\text { Total mass in each pool } \\
K_{i j}=\frac{m_{i j}}{M i}=\begin{array}{l}
\text { Albumin flow in } g / \text { day from } \\
\text { pool } i \text { to pool } j \text { as a fraction } \\
\text { of total album in in pool } i
\end{array}
\end{aligned}
$$$$
\text { Synthetic rate } K_{01}=\frac{m_{01}}{M_{1}}
$$

FIGURE 1 The model of albumin metabolism used for obtaining synthetic and catabolic rates by computer analysis.

both $K_{12}$ and $K_{21}$ were continuously variable throughout each phase. In order to generate curves for $X_{1}$ and $X_{3}$ as a function of time, equations 1 and 2 had to be solved by numerical integration. These curves were generated with an IBM 1620 digital computer with a Runge-Kutta technique (22). Computations with increments of time of 0.1 of 1 day were found to be satisfactory; this increment was small enough to avoid the introduction of appreciable errors in the solution over the maximum period of 10 days for which curves were

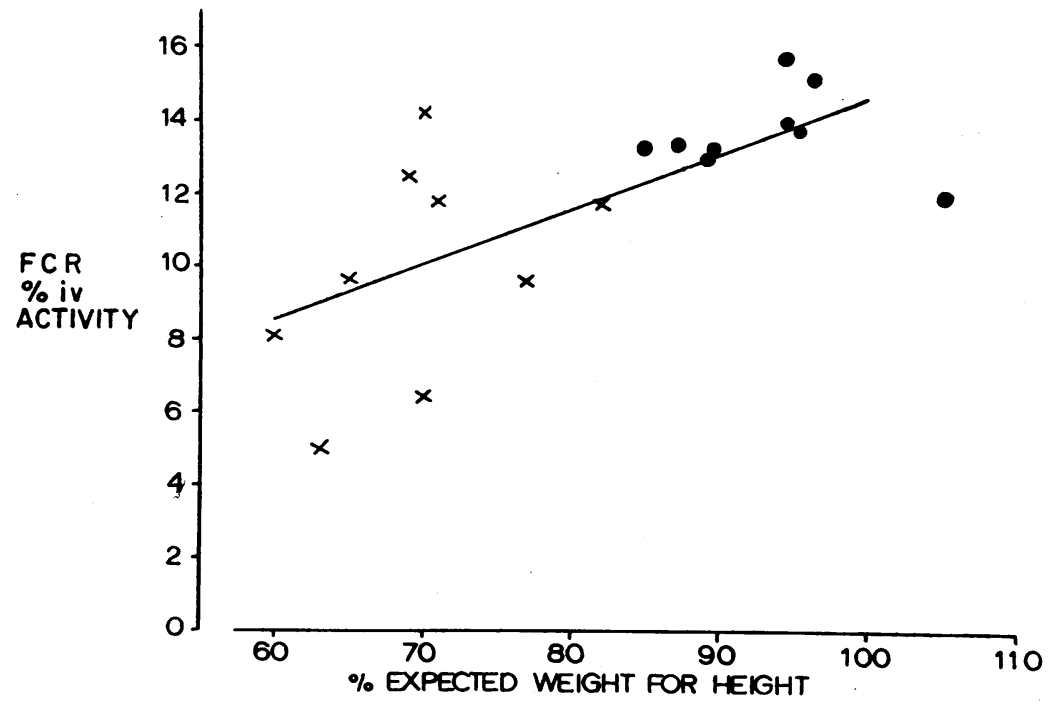

FIGURE 2 The relationship of the fractional catabolic rate (FCR) of albumin and the body weight, expressed as a percentage of weight for height, during the first phase on a high protein diet. $X=$ malnourished. $\bullet=$ recovered. 
generated. A change of $10 \%$ in any one of the rate constants usually produced a clearly detectable change in the generated curve.

The following information was required by the computer before generation of $X_{1}$ and $X_{3}$ as a function of time was possible.

I. Starting values for $X_{1}$ and $X_{3}$. For phases 2 and 3 , the initial values given by the least squares lines through the experimentally obtained points were used.

II. Trial values for $m_{01}, m_{12}$, and $m_{13}$, from which $m_{31}$ values could be calculated (see equation 4). (a) Although $m_{12}$ (and consequently $K_{12}$ ) was continuously variable throughout each phase, a single value for $m_{12}$ was obtained and was considered to represent the whole phase. (b) The value obtained for $n_{13}$ by fitting the rapidly changing intra- and extravascular total activity curves at the beginning of phase 1 was used for phases 2 and 3. Since constant values for $m_{01}, m_{12}$, and $m_{13}$ were chosen for each phase, then the value for $m_{31}$ also remained constant during each phase (equation 4). $M_{8}$ was changing with time so that a zero order relationship was assumed to exist between $m_{31}$ and $M_{3}$ (equation 6 ). A similar assumption was not required for $m_{13}$.

III. A starting value for $M_{3}$ [i.e., $\left(M_{3}\right)_{0}$ ]. Equation 5 was used to calculate $\left(M_{3}\right)_{t}$, and equation 6 gave $K_{31}$ at any time $t$. The appropriate value for $\left(M_{3}\right)_{0}$ in phase 1 was obtained by manipulating the ratio $\left(M_{8}\right)_{0} / M_{1}$ until a close fit of the initial parts of the intra- and extravascular total activity curves was obtained. In phases 2 and $3,\left(M_{3}\right)_{0}$ was taken as the value for $\left(M_{3}\right)_{t}$ existing at the end of the preceding phase.

In those children who showed an increase of more than

TABLE II

Mean Fractional and Absolute Catabolic Rates for Each Child in the Three Dietary Phases

\begin{tabular}{|c|c|c|c|c|c|c|c|c|c|}
\hline & \multicolumn{5}{|c|}{$\begin{array}{l}\text { Fractional catabolic rate } \\
\text { as a percentage of intravascular activity per day }\end{array}$} & \multicolumn{4}{|c|}{ Absolute catabolic rate } \\
\hline & & Phase & 1 & 2 & 3 & Phase & 1 & 2 & 3 \\
\hline \multirow[t]{2}{*}{ Group A } & & & & $\%$ & & \multicolumn{4}{|c|}{$m g / k g$ per day } \\
\hline & Dietary protein & & high & low & low & & & & \\
\hline M. D. & & & 15.2 & 12.0 & 9.8 & & 235 & 179 & 151 \\
\hline D. T. & & & 13.9 & 12.2 & 9.6 & & 175 & 140 & 111 \\
\hline J. H. & & & 13.0 & 9.3 & 8.5 & & 212 & 148 & 130 \\
\hline C. C. & & & 13.4 & 9.8 & 8.4 & & 259 & 194 & 168 \\
\hline Mean & & & 13.9 & 10.8 & 9.1 & & 220 & 165 & 140 \\
\hline \multicolumn{10}{|l|}{ Group B } \\
\hline & Dietary protein & & high & low & high & & & & \\
\hline W. G. & & & 13.2 & 10.7 & 10.2 & & 230 & 181 & 183 \\
\hline P. W. & & & 15.7 & 11.9 & 11.8 & & 247 & 237 & 175 \\
\hline D. S. & & & 13.7 & 10.5 & 9.1 & & 247 & 198 & 174 \\
\hline N. B. & & & 11.9 & 11.8 & 7.9 & & 170 & 167 & 114 \\
\hline D. F. & & & 11.7 & 9.3 & 9.2 & & 196 & 164 & 133 \\
\hline Mean & & & 13.2 & 10.8 & 9.6 & & 218 & 189 & 156 \\
\hline \multicolumn{10}{|l|}{ Group C } \\
\hline & Dietary protein & & high & low & low & & & & \\
\hline W. L. & & & 12.5 & 12.1 & 9.9 & & 204 & 210 & 161 \\
\hline E. B. & & & 14.2 & 11.5 & 8.0 & & 223 & 198 & 139 \\
\hline L. H. & & & 5.0 & 5.5 & 4.7 & & 85 & 96 & 87 \\
\hline F. L. & & & 9.6 & 9.0 & 6.6 & & 182 & 195 & 138 \\
\hline Mean & & & 10.3 & 9.5 & 7.3 & & 174 & 175 & 131 \\
\hline \multicolumn{10}{|l|}{ Group D } \\
\hline & Dietary protein & & high & low & high & & & & \\
\hline N. B. & & & 11.8 & 8.7 & 8.3 & & 180 & 155 & 143 \\
\hline D. F. & & & 6.4 & 6.8 & 8.8 & & 110 & 147 & 181 \\
\hline W. B. & & & 9.7 & 9.3 & 8.8 & & 146 & 144 & 136 \\
\hline P. W. & & & 8.1 & 9.2 & 11.2 & & 151 & 177 & 183 \\
\hline M. M. & & & 13.3 & 12.4 & 14.5 & & 210 & 211 & 247 \\
\hline Mean & & & 9.9 & 9.3 & 10.3 & & 159 & 167 & 178 \\
\hline
\end{tabular}


TABLE III

Average Percentage Change in Catabolic and Synthetic Rates of Albumin for Each Group, and Their Significance Limits on Altering the Dietary Protein

\begin{tabular}{|c|c|c|c|c|c|c|c|c|c|c|c|}
\hline & \multirow[b]{3}{*}{ Group } & \multirow{2}{*}{\multicolumn{4}{|c|}{ Protein intake }} & \multicolumn{2}{|c|}{$1-2$} & \multicolumn{2}{|c|}{$1-3$} & \multirow{2}{*}{\multicolumn{2}{|c|}{$2-3$}} \\
\hline & & & & & & \multirow{2}{*}{$\begin{array}{l}\text { Percent- } \\
\text { age } \\
\text { change }\end{array}$} & \multirow[b]{2}{*}{$P$} & \multirow{2}{*}{$\begin{array}{l}\text { Percent- } \\
\text { age } \\
\text { change }\end{array}$} & \multirow[b]{2}{*}{$P$} & & \\
\hline & & Phase & 1 & 2 & 3 & & & & & $\begin{array}{l}\text { Percentage } \\
\text { change }\end{array}$ & $P$ \\
\hline \multirow[t]{2}{*}{$\begin{array}{l}\text { Recovered } \\
\text { children }\end{array}$} & A & & high & low & low & $\begin{array}{l}-22 * \\
-25 \ddagger \\
-388\end{array}$ & $\begin{array}{l}<0.001 \\
<0.001 \\
<0.001\end{array}$ & $\begin{array}{l}-35 \\
-36 \\
-44\end{array}$ & $\begin{array}{l}<0.001 \\
<0.001 \\
<0.005\end{array}$ & $\begin{array}{l}-16 \\
-15 \\
-10\end{array}$ & $\begin{array}{l}<0.005 \\
<0.001 \\
\text { NS }\end{array}$ \\
\hline & B & & high & low & high & $\begin{array}{l}-18^{*} \\
-13 \ddagger \\
-298\end{array}$ & $\begin{array}{l}<0.001 \\
<0.001 \\
<0.01\end{array}$ & $\begin{array}{l}-27 \\
-28 \\
+17\end{array}$ & $\begin{array}{l}<0.001 \\
<0.001 \\
\text { NS }\end{array}$ & $\begin{array}{l}-11 \\
-17 \\
+64\end{array}$ & $\begin{array}{l}<0.005 \\
<0.01 \\
<0.001\end{array}$ \\
\hline \multirow[t]{2}{*}{$\begin{array}{l}\text { Malnourished } \\
\text { children }\end{array}$} & $\mathrm{C}$ & & high & low & low & $\begin{array}{r}-8^{*} \\
+1 \ddagger \\
-658\end{array}$ & $\begin{array}{l}<0.05 \\
\text { NS } \\
<0.001\end{array}$ & $\begin{array}{l}-29 \\
-25 \\
-56\end{array}$ & $\begin{array}{l}<0.001 \\
<0.001 \\
<0.005\end{array}$ & $\begin{array}{l}-23 \\
-25 \\
+24\end{array}$ & $\begin{array}{l}<0.001 \\
<0.001 \\
\text { NS }\end{array}$ \\
\hline & $\mathrm{D}$ & & high & low & high & $\begin{array}{r}-6^{*} \\
+5 \ddagger \\
-418\end{array}$ & $\begin{array}{l}\text { NS } \\
\text { NS } \\
<0.05\end{array}$ & $\begin{array}{r}+4 \\
+12 \\
+35\end{array}$ & $\begin{array}{l}\text { NS } \\
\text { NS } \\
\text { NS }\end{array}$ & $\begin{array}{c}+11 \\
+7 \\
+129\end{array}$ & $\begin{array}{l}\text { NS } \\
\text { NS } \\
<0.01\end{array}$ \\
\hline
\end{tabular}

NS $=$ Not significant. $\quad P>0.05$.

* The fractional catabolic rate.

$\ddagger$ The absolute catabolic rate in $\mathrm{mg} / \mathrm{kg}$ per day.

$\S$ The absolute synthetic rate in $\mathrm{mg} / \mathrm{kg}$ per day.

$10 \%$ in intravascular mass during a phase, i.e., groups $\mathrm{C}$ and $\mathrm{D}$ in phase 1 , an approximate correction was made for the rise in intravascular albumin mass. The computed synthetic rate was added to the observed rise in intravascular albumin expressed in $\mathrm{mg} / \mathrm{kg}$ per day.

\section{RESULTS}

Catabolic rate: observed values. Fig. 2 shows that there was a significant relationship between the fractional catabolic rate of albumin and an index of nutritional state $(r=0.69 ; P<0.005)$.

Table II shows the response of the mean fractional and absolute catabolic rates to dietary changes. Table III lists the percentage change of the mean catabolic rates for each group, and the statistical significance of these changes.

The recovered groups, with higher catabolic rates in phase 1 than those of malnourished children, showed a significant fall in absolute and fractional catabolic rates within the 1 st wk of low protein feeding (phase 2). A continuation of the low protein diet in phase 3 (group A) produced a further fall. Even when a high protein diet was fed in phase 3 (group B) the catabolic rate continued to fall. Malnourished children showed a different pattern of response. In phase 2 the fractional catabolic rate fell in both groups, but the fall was significant only in group $\mathrm{C}$. In the 2 nd wk on a low

protein intake, group C children showed a highly significant decrease in fractional and absolute catabolic rates; reverting to a high protein diet (group D) produced a small insignificant rise.

The change in the catabolic rate after dietary changes occurred more rapidly than could be ac-

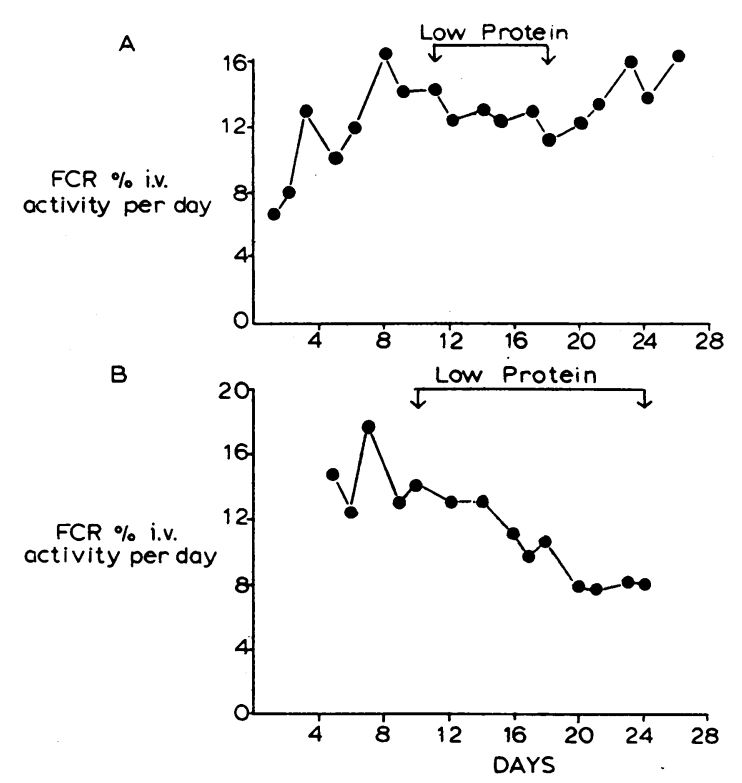

Figure 3 The effect of a low protein diet on the fractional catabolic rate of albumin. 
counted for by a change in the general nutritional state, but such changes did not always appear immediately after the diet was altered. Fig. $3 \mathrm{~A}$ shows this lag period. Subject M. M. had been in the ward 10 days on a good diet before the study. When first measured the catabolic rate was still low, but then it rose rapidly in phase 1 . Phase 2 showed a small drop in catabolic rate, but after a further short delay the rate increased again in phase 3. Fig. $3 \mathrm{~B}$ (subject E. B.) shows that the maximal effect on the catabolic rate occurred in the 2nd wk of a low protein diet.

Table IV shows the mean intravascular albumin mass for each phase. The average percentage change of these means was small, except in the malnourished children, who had a rise in intra- vascular albumin mass during phase 1 . The changes in the average weight were also small, except in group $\mathrm{D}$. These children gained weight rapidly in phases 1 and 3. This accounted for some of the variation seen in the plasma volume values in Table IV. Subject W. B. increased his absolute plasma volume from 209 to $270 \mathrm{ml}$, but successive plasma volumes expressed as $\mathrm{ml} / \mathrm{kg}$ were 53.7 , $53.3,52.4$, and $54.2 \mathrm{ml} / \mathrm{kg}$. When all plasma volume values were expressed as $\mathrm{ml} / \mathrm{kg}$ of body weight there was no consistent change during any phase.

In all recovered, and in most of the malnourished children, the computer-generated curves fitted the experimental points very closely. A typical set of results, from patient W. G. 2, is shown in

TABLE IV

Mean Body Weight, Plasma Volume and Mean Total Intravascular Albumin Mass in Each Phase

\begin{tabular}{|c|c|c|c|c|c|c|c|c|c|c|c|}
\hline & \multicolumn{4}{|c|}{ Mean body wt } & \multicolumn{4}{|c|}{ Plasma volume* } & \multicolumn{3}{|c|}{ Intravascular albumin mass } \\
\hline & Phase & 1 & 2 & 3 & Initial Phase & 1 & 2 & 3 & Phase & 2 & 3 \\
\hline & & & $k g$ & & & & & & & $g$ & \\
\hline \multicolumn{12}{|l|}{ Group A } \\
\hline M. D. & & 6.93 & 7.02 & 6.89 & 360 & 356 & 320 & 360 & 10.66 & 10.33 & 10.81 \\
\hline D. T. & & 8.49 & 8.47 & 8.40 & 425 & 344 & 323 & 332 & 11.46 & 9.66 & 9.71 \\
\hline J. H. & & 9.05 & 9.11 & 9.06 & 420 & 400 & 382 & 359 & 14.88 & 14.38 & 13.81 \\
\hline C. C. & & 6.05 & 6.28 & 6.35 & 332 & 348 & 350 & 350 & 11.46 & 12.57 & 12.52 \\
\hline \multicolumn{10}{|c|}{ mean percentage change } & $-3 \%$ & $0 \%$ \\
\hline \multicolumn{12}{|l|}{ Group B } \\
\hline W. G. & & 7.59 & 7.68 & 7.79 & 356 & 355 & 330 & 343 & 12.88 & 12.76 & 13.66 \\
\hline P. W. & & 7.45 & 7.77 & 8.16 & 340 & 347 & 328 & 353 & 11.57 & 11.67 & 12.26 \\
\hline D. S. & & 7.58 & 7.56 & 7.78 & 372 & 373 & 372 & 390 & 13.52 & 13.79 & 14.73 \\
\hline N. B. & & 7.82 & 7.55 & 7.91 & 377 & 343 & 332 & 377 & 11.54 & 10.80 & 11.51 \\
\hline D. F. & & 5.62 & 5.43 & 5.92 & 320 & 318 & 305 & 288 & 9.38 & 9.56 & 8.53 \\
\hline \multicolumn{10}{|c|}{ mean percentage change } & $-1 \%$ & $+4 \%$ \\
\hline \multicolumn{12}{|l|}{ Group C } \\
\hline W. L. & & 6.28 & 6.26 & 6.24 & 340 & 340 & 343 & 343 & 9.86 & 10.76 & 10.11 \\
\hline E. B. & & 5.37 & 5.37 & 5.37 & 308 & 273 & 306 & 294 & 8.29 & 9.28 & 9.38 \\
\hline L. H. & & 4.35 & 4.29 & 4.23 & 273 & 281 & 281 & 281 & 6.02 & 7.46 & 7.94 \\
\hline \multirow[t]{2}{*}{ F. L. } & & 4.77 & 4.61 & 4.58 & 264 & 277 & 292 & 292 & 8.91 & 10.13 & 9.63 \\
\hline & & & & & & & \multicolumn{3}{|c|}{ mean percentage change } & $+11 \%$ & $-2 \%$ \\
\hline \multicolumn{12}{|l|}{ Group D } \\
\hline N. B. & & 4.64 & 4.67 & 4.85 & 272 & 256 & 260 & 265 & 7.30 & 8.29 & 8.33 \\
\hline D. F. & & 3.61 & 3.56 & 3.88 & 240 & 260 & 250 & 241 & 5.97 & 7.68 & 7.94 \\
\hline W. B. & & 4.32 & 4.59 & 4.80 & 209 & 240 & 239 & 270 & 5.88 & 7.12 & 7.37 \\
\hline P. W. & & 4.14 & 4.31 & 4.68 & 247 & 239 & 289 & 258 & 7.93 & 8.33 & 7.65 \\
\hline \multirow[t]{2}{*}{ M. M. } & & 4.44 & 4.58 & 4.93 & 270 & 210 & 225 & 223 & 7.32 & 7.78 & 8.28 \\
\hline & & & & & & & \multicolumn{3}{|c|}{ mean percentage change } & $+11 \%$ & $+1 \%$ \\
\hline
\end{tabular}

* Measured at the end of each phase. 
Fig. $4 \mathrm{~A}$. Table $\mathrm{V}$ gives the values for the intraand extravascular activity used in the computation, together with the values for the serum albumin level. The plasma volume measurements are included in Table IV. Two malnourished children, L. H. and M. M., had experimental results that were difficult to fit with computed curves in phase
1. Dividing the phase into two parts at $72 \mathrm{hr}$ after injection with increased values for synthetic and catabolic rates in part 2 improved the fit. This is shown in Fig. 4 B.

Table VI shows the computer-derived values for synthetic and catabolic rates. The calculated absolute synthetic rates are given together with

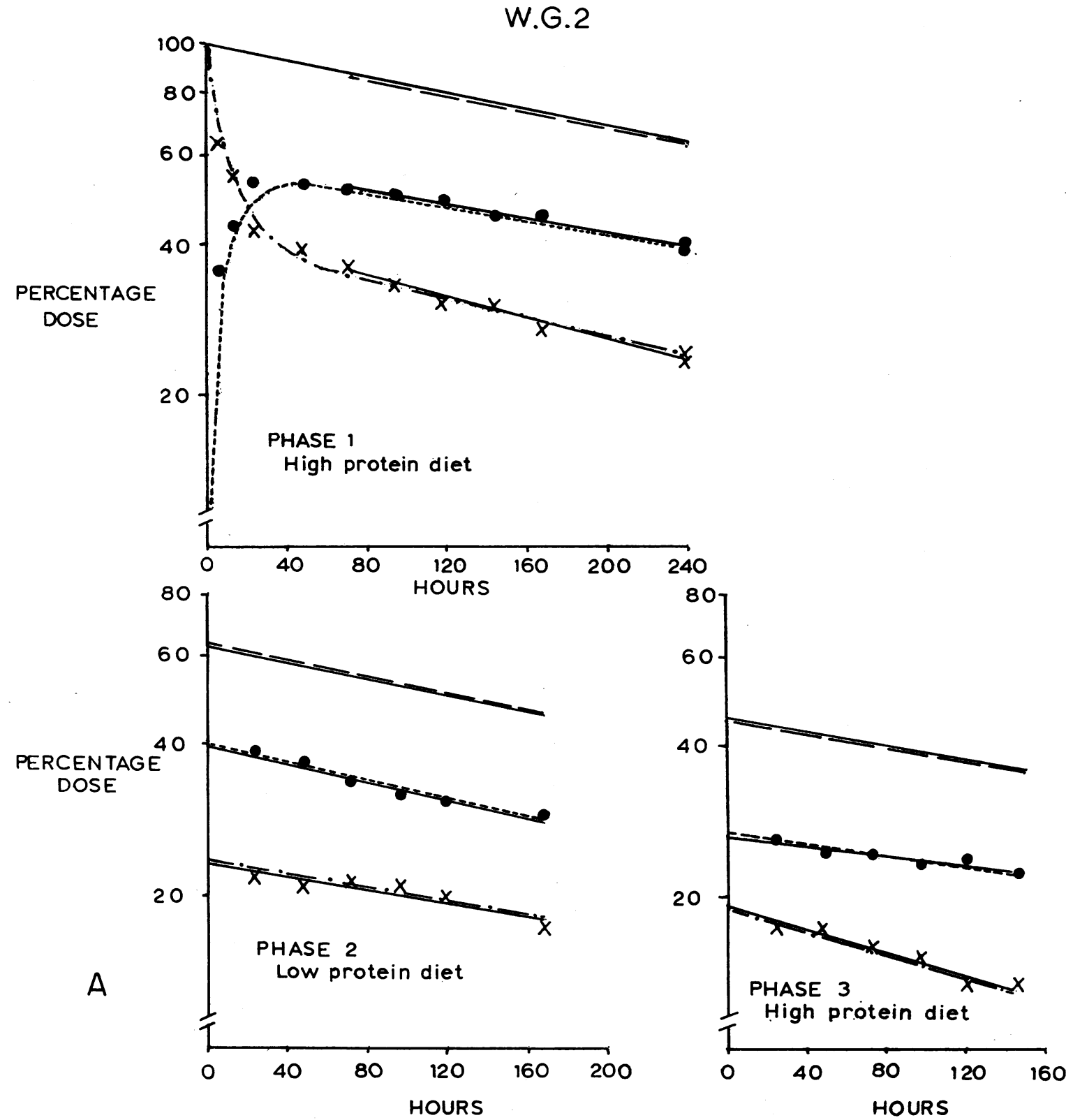

FIGURE $4 \mathrm{~A}$ and $\mathrm{B}$ Experimental results for two children with calculated regression lines and computer-generated curves to simulate the experimental data. Continuous lines $=$ calculated regression lines. Dotted lines $=$ generated curves. $=$ total extravascular activity as a percentage of dose. $X=$ total intravascular activity as a percentage of dose. Whole body-corrected least squares line only shown without experimental points. 


\section{L.H.1}

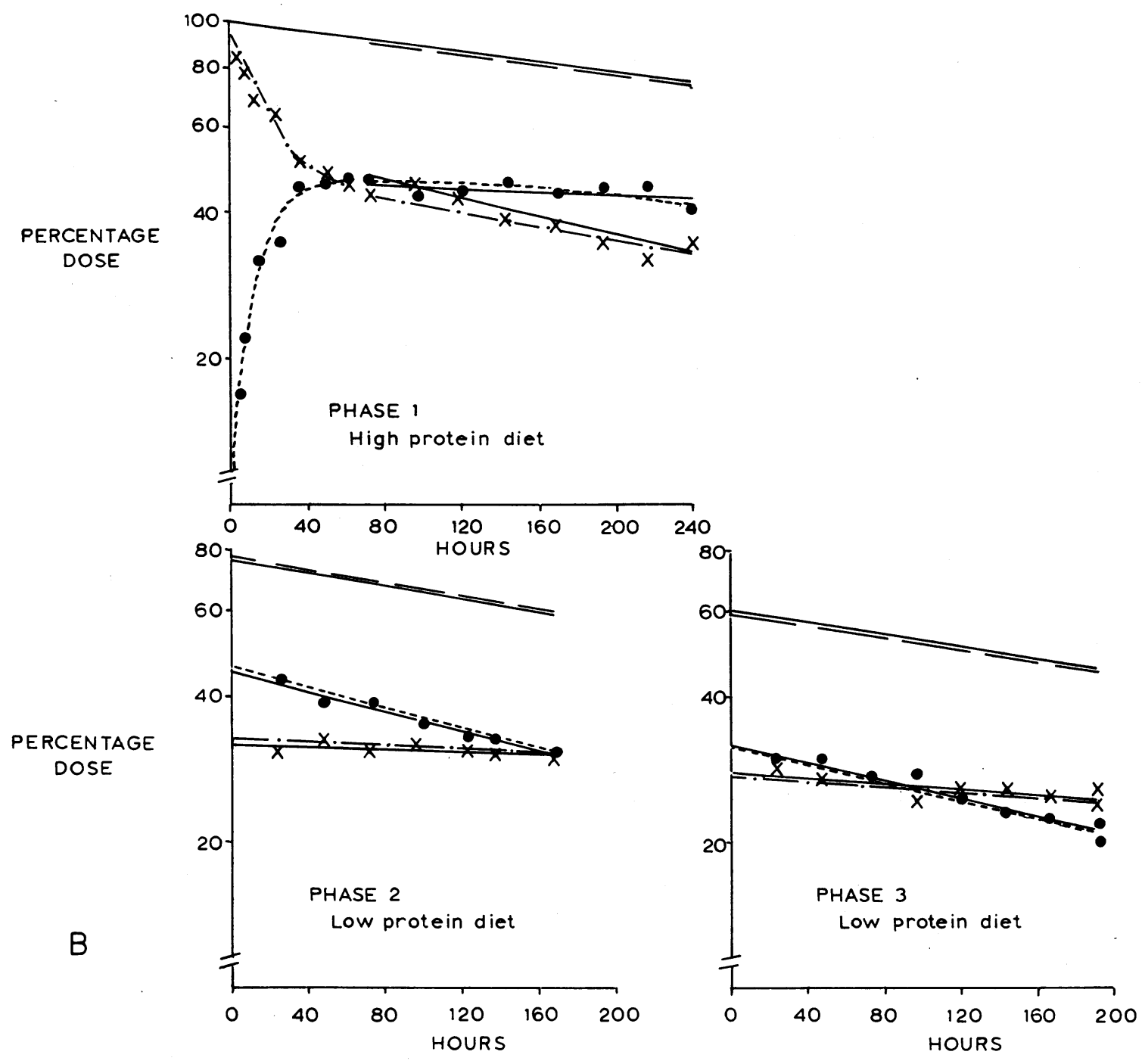

Figure $4 \mathrm{~A}$ and $\mathrm{B}$ Continued

the corrected absolute synthetic rate values in phase 1 for malnourished children. There was no significant difference between the mean synthetic rates of malnourished and recovered children in phase 1 , even when the corrected values were used. The extent and significance of the changes in synthetic rate between phases are included in Table III.

The absolute and fractional synthetic rates were very sensitive to changes in the level of protein intake. The early change in slope of the intra- and extravascular curves after altering the diet indi- cates that changes in synthesis take place more rapidly than the slower adjustments in the catabolic rate measured by changes in urine activity. Comparison of the synthetic rates in the malnourished and recovered children shows that the former were much more sensitive to changes in both directions on altering the protein intake. When the protein intake was reduced in phase 2 , the mean percentage fall in synthesis rate was $33 \%$ (in recovered) and 55\% (in malnourished children). This was a significant difference $(P<$ $0.01)$. In phase 3 the mean synthetic rate on 
TABLE $\mathrm{V}$

Calculated Total Intra- and Extravascular Activities and the Serum Albumin Concentrations from a Recovered Child, W. G.

\begin{tabular}{|c|c|c|c|}
\hline Time & $\begin{array}{c}\text { Total } \\
\text { intravascular } \\
\text { activity }\end{array}$ & $\begin{array}{c}\text { Total } \\
\text { extravascular } \\
\text { activity }\end{array}$ & $\begin{array}{c}\text { Serum } \\
\text { albumin } \\
\text { concentration }\end{array}$ \\
\hline hrs & $\%$ dose & $\%$ dose & $\mathrm{g} / 100 \mathrm{ml}$ \\
\hline \multicolumn{4}{|l|}{ Phase 1} \\
\hline 0.17 & 100.0 & 0 & 3.82 \\
\hline 0.50 & 96.3 & 3.6 & 3.82 \\
\hline 6.25 & 63.6 & 35.1 & 3.63 \\
\hline 12.25 & 54.6 & 43.0 & 3.51 \\
\hline 23.25 & 42.5 & 53.1 & 3.63 \\
\hline 47.25 & 38.7 & 52.5 & 3.22 \\
\hline 70.25 & 36.2 & 51.0 & 3.45 \\
\hline 94.25 & 33.4 & 49.8 & 3.70 \\
\hline 118.25 & 30.5 & 48.8 & 3.57 \\
\hline 143.00 & 30.0 & 45.6 & 3.94 \\
\hline 166.25 & 26.9 & 45.3 & 3.61 \\
\hline 239.07 & 24.0 & 38.7 & 3.67 \\
\hline 239.25 & 22.7 & 40.0 & 3.50 \\
\hline \multicolumn{4}{|l|}{ Phase 2} \\
\hline 23.00 & 21.8 & 38.4 & 3.70 \\
\hline 47.00 & 20.9 & 36.7 & 3.95 \\
\hline 71.00 & 21.4 & 33.7 & 3.89 \\
\hline 95.00 & 20.9 & 31.7 & 3.61 \\
\hline 119.00 & 19.9 & 30.4 & 3.61 \\
\hline 168.00 & 17.1 & 28.9 & 3.61 \\
\hline \multicolumn{4}{|l|}{ Phase 3} \\
\hline 24.25 & $17 . \dot{5}$ & 25.9 & 3.72 \\
\hline 48.07 & 17.4 & 24.4 & 3.92 \\
\hline 72.50 & 16.0 & 24.2 & 3.72 \\
\hline 96.25 & 15.1 & 23.5 & 3.78 \\
\hline 120.75 & 13.3 & 23.9 & 3.95 \\
\hline 145.00 & 13.3 & 22.4 & 3.58 \\
\hline
\end{tabular}

continuing the low protein diet rose in group C (malnourished children), but fell further in group A (recovered children).

The computer derived values for fractional catabolic rates in Table VI tend to be higher than the observed values (Table II).

Fig. 5 shows the effect of dietary phases on the net transfer of albumin from the intravascular to the extravascular pool. All the malnourished and most of the recovered children on a high protein intake in phases 1 and 3 had a net transfer of albumin into the extravascular pool. Two recovered children were in a steady state in phase 1 with no net transfer. Three recovered children in phase 1 had a net transfer of albumin into the intravascular pool on a high protein diet; two of the three chil- dren developed an infection during the phase. Children in both nutritional groups transferred albumin into the intravascular pool in phase 2 . This net transfer of albumin into the intravascular pool was reduced in phase 3 in all those children who continued on a low protein diet, and two recovered subjects had a net transfer of albumin into the extravascular pool. This decrease in phase 3 was due to a combination of increased synthesis with reduced catabolism in the malnourished children, and a marked fall in the fractional catabolic rate in the recovered group.

\section{DISCUSSION}

Whole body counting was necessary for the estimation of the total retained activity in this study. Continuous urine collections for a period lasting 24 days were not possible in infants, half of whom were malnourished, and extrapolation from intermittent collections may have introduced errors which would be cumulative.

These difficulties were avoided by whole body counting which has been used in tracer studies on albumin and globulin metabolism in animals and humans (23-26).

Errors in whole body counting arise from geometric differences between the standard and the

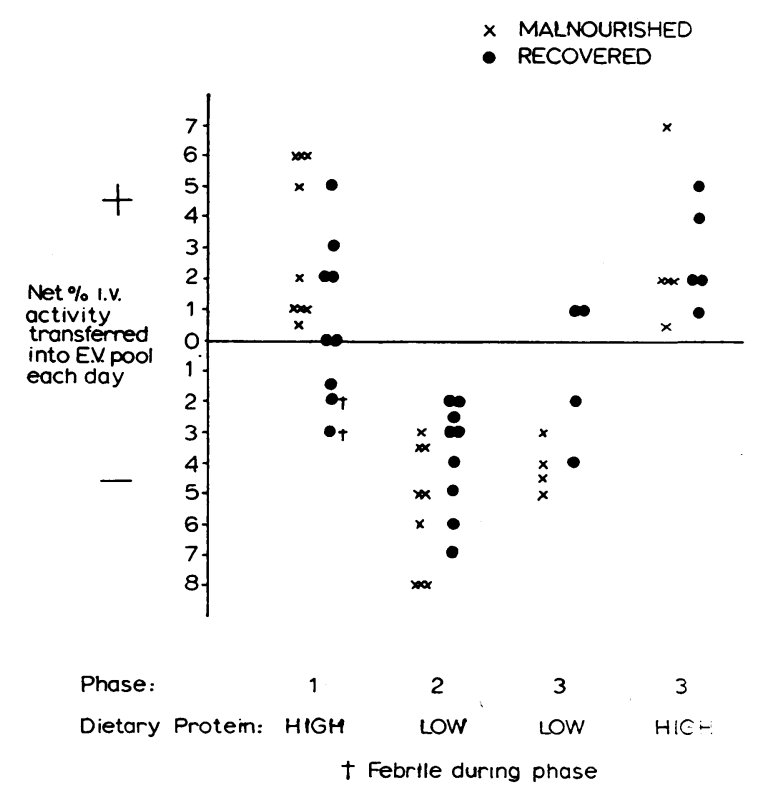

Figure 5 The net transfer of albumin per day into the extravascular pool as a percentage of the intravascular activity during each phase. 
TABLE VI

Values for the Catabolic and Synthetic Rates of Albumin Derived by Computer Analysis, and the Calculated Corrected Absolute Synthetic Rate in Malnourished Children in Phase 1

\begin{tabular}{|c|c|c|c|c|c|c|c|c|c|c|c|c|}
\hline & \multicolumn{4}{|c|}{ Absolute synthetic rate } & \multicolumn{4}{|c|}{$\begin{array}{l}\text { Fractional synthetic rate, intra- } \\
\text { vascular mass per day }\end{array}$} & \multicolumn{4}{|c|}{$\begin{array}{l}\text { Fractional catabolic rate, intra- } \\
\text { vascular mass per day }\end{array}$} \\
\hline & Phase. . & 1 & 2 & 3 & Phase.. & 1 & 2 & 3 & Phase. . & 1 & 2 & 3 \\
\hline Group A & \multicolumn{4}{|c|}{$m g / k g$ per day } & \multicolumn{4}{|c|}{$\%$} & \multicolumn{4}{|c|}{$\%$} \\
\hline M. D. & & 231 & 162 & 94 & & 15 & 11 & 6 & & 15 & 16 & 10 \\
\hline D. T. & & 270 & 148 & 116 & & 20 & 13 & 10 & & 15 & 16 & 12 \\
\hline J. H. & & 247 & 142 & 183 & & 15 & 9 & 12 & & 12 & 12 & 11 \\
\hline C. C. & & 237 & 160 & 158 & & 12.5 & 8 & 8 & & 14 & 14 & 9 \\
\hline Mean & & 246 & 153 & 138 & & & & & & & & \\
\hline \multicolumn{13}{|l|}{ Group B } \\
\hline W. G. & & 221 & 150 & 263 & & 13 & 9 & 15 & & 11 & 11 & 11 \\
\hline P. W. & & 233 & 105 & 225 & & 15 & 7 & 15 & & 15 & 14 & 13 \\
\hline D. S.* & & 187 & 182 & 227 & & 10.5 & 10 & 12 & & 12.5 & 12.5 & 10 \\
\hline N. B. & & 221 & 143 & 204 & & 15 & 10 & 14 & & 13 & 14 & 13 \\
\hline D. F.* & & 150 & 141 & 259 & & 9 & 8 & 18 & & 12 & 10 & 13 \\
\hline Mean & & 202 & 144 & 236 & & & & & & & & \\
\hline \multicolumn{13}{|l|}{ Group C } \\
\hline W. L. & & $204(233) \ddagger$ & 103 & 97 & & 13 & 6 & 6 & & 12 & 12 & 11 \\
\hline E. B. & & $247(260)$ & 69 & 79 & & 16 & 4 & 4.5 & & 10 & 12 & 9 \\
\hline L. H. & & $152(189)$ & 43 & 66 & & 11 & 2.5 & 3.5 & & 6 & 7 & 6.5 \\
\hline F. L. & & $187(221)$ & 66 & 105 & & 10 & 3 & 5 & & 9 & 11 & 9 \\
\hline Mean & & $198(226)$ & 70 & 87 & & & & & & & & \\
\hline \multicolumn{13}{|l|}{ Group D } \\
\hline N. B. & & $205(220)$ & 89 & 198 & & 13 & 5 & 11.5 & & $\cdot 12.5$ & 10 & 11 \\
\hline D. F. & & $182(232)$ & 108 & 430 & & 11 & 5 & 21 & & 10 & 10 & 13 \\
\hline W. B. & & $136(194)$ & 124 & 200 & & 10 & 8 & 13 & & 8 & 11 & 11 \\
\hline P. W. & & $249(254)$ & 116 & 311 & & 13 & 6 & 19 & & 7 & 14 & 17 \\
\hline M. M. & & 297 (297) & 195 & 302 & & 18 & 11.5 & 18 & & 12 & 15 & 16 \\
\hline Mean & & $214(239)$ & 126 & 288 & & & & & & & & \\
\hline
\end{tabular}

* Febrile during phase one.

$\ddagger$ Calculated corrected absolute synthetic rate.

body, and from self-absorption of ${ }^{181} \mathrm{I}$ radiation by the body. The correction of the intercept of the least squares line for whole body activities more than three days after injection, to give equivalent count rates for the standard and subject, avoided errors of geometry and self-absorption. Self-absorption decreased during the first $24-48 \mathrm{hr}$, presumably related to the extravascular mixing of albumin-131I. The difference between the initial and final self-absorption varied between subjects and averaged $5 \%$ of the dose. Similar findings in adults have been reported (27). The method of correction for both geometry and self-absorption introduced an error by ignoring the normal increased loss of radioactivity in the 1st or 2nd day after injection. This latter error may increase the figure for the total retained dose by $3-4 \%$. Preliminary studies with continuous urine collections and whole body counting showed that there was usually a discrepancy of less than $2 \%$ between the total retained activity calculated from whole body counting and cumulative urinary excretion.

The whole body counter can measure the retained activity at the end of the study (about 20\% of the initial dose) with a statistical accuracy of $1 \%$, but small daily changes in the low rates of 
albumin degradation in malnourished children are difficult to detect by this technique. Therefore, measurement of the total $24 \mathrm{hr}$ urine activity in the counter was necessary for showing these small changes in catabolic rate, and whole body counting for measuring the total retained activity.

Any retention of inorganic ${ }^{131} \mathrm{I}$ by the body would exaggerate the values of the retained dose. If this were a continuous accumulation of ${ }^{131} \mathrm{I}$ by the body throughout the study, e.g., in the extravascular fluid, thyroid, or gastric mucosa, this would reduce the fall in extravascular activity, and result in an underestimate of the fractional catabolic rate on computer analysis. This error would be greatest at the end of the study. Comparison in phase 3 of computed catabolic rates and fractional catabolic rates calculated from urinary excretion does not support this possibility.

In all except two experiments the children were initially in a nonsteady state, and dietary changes for phases 2 and 3 also produced nonsteady-state conditions: methods which assume a steady state cannot be used to analyze our data. Matthews' model for the separate estimation of synthesis and transfer in nonsteady-state conditions has been used with digital computation in the present investigations. In only two malnourished patients was there any difficulty in fitting the experimental points with generated curves.

The simplification of the model and the use in computation of a single value for the fractional catabolic rate during the phase may explain, however, the discrepancy found in some cases between the computer-derived and experimental values for fractional catabolic rates; the latter were known to change rapidly during a phase. The computerderived value for the catabolic rate usually showed a more delayed and smaller change than the observed values (group A in phase 3 ).

Catabolic rate: effect of nutritional state and levels of protein intake. The malnourished children had a statistically lower fractional and absolute catabolic rate than recovered children. This agreed with previous observations in children and hypoalbuminaemic adults $(2,3,5)$. The published studies show a low catabolic rate in malnourished children when given either a high or a low protein diet. This would suggest that the most important factor in determining the catabolic rate was the child's nutritional state, and that the catabolic rate could be expected to return slowly to normal as the nutritional state improved.

The present results show that this is an oversimplification. A malnourished child fed a high protein diet had a normal catabolic rate within 2-3 wk and a recovered child fed a low protein diet showed a fall in catabolic rate within 7 days. Investigations in healthy adults have shown that a preliminary period of 3-6 wk on a low protein diet will produce a reduction in albumin catabolic rate (28) but Iber, Nassau, Plough, Berger, Meroney, and Frement-Smith (29) and Hoffenberg, Black, and Brock (5) showed that this fall could occur within a few days of low feeding. This supports the conclusion that the dietary intake and not the general nutritional state is the more important influence in determining the catabolic rate; and variable values for the catabolic rate in the malnourished children are to be expected during the initial period of study, because the children had differing protein intakes before starting the investigation.

Studies of the daily changes in fractional catabolic rate after a change of diet showed that the effect on the catabolic rate did not occur immediately, and was most marked during the 2 nd wk (Fig. 3 B). Children in group B, who received a low protein diet in phase 2 , showed a further fall in catabolic rate in phase 3 on a high protein diet. The catabolic rate seemed to reflect the previous week's protein intake, but the delay of 3-5 days before the rate fell demonstrated that the protein intake did not directly control the catabolic rate but influenced some intermediate mechanism. Delayed changes in catabolic rate after varying the level of dietary protein were also found by Hoffenberg et al. in four adults (5).

The present studies also showed changes in catabolic rate without alterations in serum albumin concentration which Freeman and Gordon considered as a possible controlling mechanism (24). Matthews' work on rabbits (8) and adult studies (5) have also shown catabolic rate changes without concomitant changes in serum albumin concentration.

The present study emphasizes that the catabolic rate does not respond directly to changes in synthetic rate. In phase 3 , group $B$ showed a fall in fractional catabolic rate with a rise in synthetic rate (Table III). Bauman, Rothschild, Yalow, and 
Berson (30) also showed a normal synthetic rate with reduced catabolism in subjects with proteinuria in a steady state. Animal experiments with plasmapheresis and ad libitum feeding showed similar changes (4), and separate measurement of the synthetic rate by Matthews demonstrated this effect more directly (8).

Other factors, particularly hormonal, may affect the catabolic rate of albumin. Increased catabolism occurs in Cushing's disease and during the administration of cortisone and adrenocorticotrophin (ACTH) (31-34). Similarly, an increased rate occurs in thyrotoxicosis and after administration of thyroid hormone and triiodothyronine $(35,36,29)$. Growth hormone produces a decrease in the factional catabolic rate of albumin, but anabolic steroids have no effect $(37,38)$.

In malnutrition, both cortisol and growth hormone levels are raised, but thyroid function is within normal limits (39-41). It has been shown that an increase in protein intake produces a fall in human growth hormone levels (42) and Pimstone, Wittmann, Hansen, and Murray (40) found a marked fall in plasma growth hormone levels within 1 or 2 wk in malnourished children on a high protein diet. The rise in the catabolic rate in malnourished children on a good protein intake (Fig. $3 \mathrm{~A}$ ) may have been mediated therefore by a reduction in growth hormone levels.

Synthetic rate. The derived values for the fractional synthetic rate presume a constant intravascular albumin mass. Table IV shows that this was not constant in the malnourished groups. The percentage increase of $11 \%$ in the means from phase 1 to 2 , although an underestimate of the rise in intravascular albumin mass in phase 1 in some children, was less than expected in view of the known rapid rise in serum albumin in recovering malnourished children (43). This rise was minimized by the design of the present study, since mainly nonedematous marasmic children were chosen, whose serum albumin levels were not particularly low (44). The three children admitted with mild edema were kept on a high protein diet up to 10 days until free from edema before the study was begun.

Where the rise in intravascular albumin mass occurred, the synthetic rate obtained from computer analysis was underestimated. Some of the newly synthesized albumin entering the intravascu- lar pool remained there and was not represented in the analysis, either as catabolized or transferred albumin. An approximate correction of the absolute synthetic rate was made by adding the increase in intravascular albumin mass to the absolute rate. The child with the lowest computed synthetic rate, W. B., showed the greatest rise in intravascular albumin mass during the 1st phase. Similar corrections for the other malnourished children in phase 1 considerably reduced the range of values, but did not make the synthetic rate in these patients significantly higher than in the recovered children in phase 1 . This normal synthetic rate in malnourished children occurred despite the known fatty infiltration and the low protein content of the liver in malnutrition (45).

The synthetic rate in phase 2 was significantly lower in the malnourished than in the recovered children. This may reflect a reduced supply of amino acids liberated by catabolism of tissue protein. When the low protein diet was continued (groups $A$ and $C$ in phase 3 ), the synthetic rate continued to fall in the recovered children, but was maintained or rose slightly in the malnourished group. The malnourished child may be able to make more efficient use of the reduced supply of amino acids, as a result of adaptive changes associated with increased hepatic amino acid-activating enzymes and increased recycling of amino acids for protein synthesis (46).

Extravascular mass. No attempt has been made to measure the extravascular albumin mass from the experimental findings. It seems reasonable to assume, however, that the large changes in extravascular activity reflect similar changes in extravascular mass. The computer-derived figure for the extravascular mass, based on equations for the nonsteady state, gave results in phase 1 that were very similar to the activity distribution ratios at the height of the extravascular activity curve. The immediate fall in the extravascular activity in phase 2 is associated with a fall in the albumin synthetic rate. Plasmapheresis or bleeding of animals on normal protein intakes, with presumably normal or increased synthetic rates, also produces a fall in extravascular mass $(47,48)$. This suggests that the shift in albumin into the intravascular compartment is related to the depletion of intravascular albumin mass per se, and not to the process by which this occurs. 
The immediate and initial response to a reduction in protein intake appears to be a fall in the albumin synthetic rate. If synthesis is closely related to the intravascular compartment, this would lead to a reduction in intravascular albumin mass, unless compensatory mechanisms come into play. Our results suggest that any tendency to change the total intravascular albumin mass is minimized by a change in the direction or rate of net albumin transfer between the intra- and extravascular pools. In addition there appears to be a "feedback" system involving the catabolic rate; changes in total albumin mass are minimized by compensatory adjustments in the catabolic rate.

These two mechanisms were suggested by Hoffenberg et al. (5) as two factors which could operate to maintain the intravascular albumin mass. The fall in extravascular albumin may also lead to a reduction in the hepatic interstitial albumin concentration, which in turn may stimulate albumin synthesis (49).

The state of adaptation to a low protein intake appears from the present investigations to be associated with a low catabolic rate to compensate for a reduced synthetic rate; the intravascular albumin mass is kept constant at the expense of the extravascular albumin; although albumin synthesis is low, the capacity to return to a normal rate is retained, so that an immediate response is possible as soon as the amino acid supply improves. Finally, there may be more economical utilization of amino acids for albumin synthesis, perhaps as a result of adaptive enzyme changes in the liver with increased amino acid recycling.

\section{ACKNOWLEDGMENTS}

We wish to thank the nursing staff, Mrs. Ragbeer and Miss Pearl Stephenson, for their technical assistance and Mrs. J. Bayley-Hay for her help with the manuscript. We thank Dr. T. Freeman for his advice on the iodination of albumin and Dr. G. A. O. Alleyne and Dr. D. Picou for their criticism of the manuscript. We are indebted to Professor Waterlow for encouragement and advice throughout the study.

A. M. Hay was supported by a research fellowship from the Wellcome Trust, London.

\section{REFERENCES}

1. Gitlin, D., J. Cravioto, S. Frenk, E. L. Montano, R. R. Galvan, F. Gomez, and C. A. Janeway. 1958. Albumin metabolism in children with protein malnutrition. J. Clin. Invest. 37: 682.
2. Picou, D., and J. C. Waterlow. 1962. The effect of malnutrition on the metabolism of plasma albumin. Clin. Sci. 22: 459.

3. Cohen, S., and J. D. L. Hansen. 1962. Metabolism of albumin and $\boldsymbol{\gamma}$ globulin in kwashiorkor. Clin. Sci. 23: 351 .

4. Matthews, C. M. E. 1961. Effects of plasmapheresis on albumin pools in rabbits. J. Clin. Invest. 40: 603.

5. Hoffenberg, R., E. Black, and J. F. Brock. 1966. Albumin and $\gamma$ globulin tracer studies in protein depletion states. J. Clin. Invest. 45: 143.

6. Waterlow, J. C. 1962. Protein malnutrition and albumin breakdown. Lancet. 2: 1279.

7. Matthews, C. M. E. 1965. Application of an analogue computer to analysis of experiments with $\mathrm{I}^{181}$ labelled plasma proteins when pools are not in dynamic equilibrium. In Radioaktive Isotope in Klinik und Forshung. K. Fellinger and R. Höfer, editors. Urban and Schwarzenberg, Munich. 240.

8. Matthews, C. M. E. 1965. The use of computers in the study of protein turnover. In Radioisotope Techniques in the Study of Protein Metabolism. Technical Reports Series No. 45. International Atomic Energy Agency. 105.

9. Nelson, W. E. 1959. Textbook of Pediatrics. W. B. Saunders, Co., Philadelphia. 7th edition. 50.

10. Chan, H., and J. C. Waterlow. 1966. The protein requirement of infants at the age of about one year. Brit. J. Nutr. 20: 775.

11. Garrow, J. S. 1965. The use and calibration of a small whole body counter for the measurement of total body potassium in malnourished infants. West Indian Med. J. 14: 73.

12. McFarlane, A. S. 1956. Labelling of plasma proteins with radioactive iodine. Biochem. J. 62: 135.

13. McFarlane, A. S. 1958. Efficient trace-labelling of proteins with iodine. Nature. 182: 53.

14. Freeman, T. 1959. The biological behaviour of normal and denatured human plasma albumin. Clin. Chim. Acta. 4: 788.

15. Cohen, S., T. Freeman, and A. S. McFarlane. 1961. Metabolism of $\mathrm{I}^{\text {sal }}$ labelled human albumin. Clin. Sci. 20: 161

16. Debro, J. R., H. Tarver, and A. Korner. 1957. The determination of serum albumin and globulin by $a$ new method. J. Lab. Clin. Med. 50: 728.

17. Lowry, O. H., N. J. Rosebrough, A. L. Farr, and R. J. Randall. 1951. Protein measurement with the Folin phenol reagent. J. Biol. Chem. 193: 265.

18. Bonsnes, R. W., and H. H. Taussky. 1945. On the colorimetric determination of creatinine by the Jaffe reaction. J. Biol. Chem. 158: 581.

19. Constable, B. J. 1958. Estimation of Evans blue dye in blood plasma and its application to blood volume determination. Clin. Sci. 17: 597.

20. Leonard, P. J., J. G. Banwell, and M. H. Craggs. 1964. The simultaneous measurement of plasma volume using Evans' blue (T-1824) and $\mathrm{I}^{120}$-labelled human serum albumin. E. African Med. J. 41 : 55. 
21. Fisher, R. A. 1958. Statistical Methods for Research Workers. Oliver and Boyd, Edinburgh. 13th edition.

22. Mathematical methods for digital computers. A. Ralston and H. S. Wilf, editors. 1960. John Wiley and Sons, Inc., New York.

23. Campbell, R. M., D. P. Cuthbertson, C. M. Matthews, and A. S. McFarlane. 1956. Behaviour of $\mathrm{C}^{14}$ and $\mathrm{I}^{181}$ labelled plasma proteins in the rat. Intern. J. Appl. Radiation Isotopes. 1: 66.

24. Freeman, T., and A. H. Gordon. 1964. Metabolism of albumin and $\gamma$ globulin in protein deficient rats. Clin. Sci. 26: 17.

25. Lippincott, S. W., S. H. Cohn, H. Hamel, S. Fine, and S. Korman. 1961. Determination of radioactively labeled globulin turnover by the direct whole-body counting technique. J. Clin Invest. 40: 697.

26. Lippincott, S. W., S. H. Cohn, J. S. Robertson, and L. E. Farr. 1961. In-vivo measurement by the wholebody gamma spectrometer of the degradation rate of $\mathrm{I}^{181}$ labeled normal albumin. Lab. Invest. 10: 481.

27. Rossing, N., and O. Bärenholdt. 1967. Whole-body counting in metabolic studies of ${ }^{181}$ I-labelled albumin. Scand. J. Clin. Lab. Invest. 19: 331.

28. Hoffenberg, R., S. Saunders, G. C. Linder, E. Black, and J. F. Brock. 1962. $\mathrm{I}^{131}$-albumin metabolism in human adults after experimental protein depletion and repletion. In Protein Metabolism. F. Gross, editor. Springer-Verlag, Berlin. 314.

29. Iber, F. L., K. Nassau, I. C. Plough, F. M. Berger, W. H. Meroney, and K. Fremont-Smith. 1958. The use of radioiodinated albumin in metabolic studies. The effects of the level of dietary protein and 1-triiodothyronine on the catabolism of radioiodinated human serum albumin. J. Clin. Invest. 37: 1442.

30. Bauman, A., M. A. Rothschild, R. S. Yalow, and S. A. Berson. 1955. Distribution and metabolism of $\mathrm{I}^{131}$-labeled human serum albumin in congestive heart failure with and without proteinuria. J. Clin. Invest. 34: 1359.

31. Sterling, K. 1960. The effect of Cushing's syndrome upon serum albumin metabolism. J. Clin. Invest. 39: 1900.

32. Rothschild, M. A., S. S. Schreiber, M. Oratz, and H. L. McGee. 1958. The effects of adrenocortical hormones on albumin metabolism studied with albumin- $\mathrm{I}^{131}$. J. Clin. Invest. 37: 1229.

33. Rothschild, M. A., M. Oratz, E. Wimer, and S. S. Schreiber. Studies on albumin synthesis: the effects of dextran and cortisone on albumin metabolism in rabbits studied with albumin- $\mathrm{I}^{121}$. J. Clin. Invest. 40: 545.

34. Grossman, J., A. A. Yalow, and R. E. Weston. 1960. Albumin degradation and synthesis as influenced by hydrocortisone, corticotrophin and infection. Metab. Clin. Exptl. 9: 528.

35. Blomstedt, B., and S.-O. Liljedahl. 1967. Effect of hyperthyroidism on metabolism of albumin in man. Acta Med. Scand. 181: 315.

36. Rothschild, M. A., A. Bauman, R. S. Yalow, and S. A. Berson. 1957. The effect of large doses of desiccated thyroid on the distribution and metabolism of albumin $\mathrm{I}^{131}$ in euthyroid subjects. J. Clin. Invest. 36: 422 .

37. Gabuzda, T. G., H. Jick, and T. G. Chalmers. 1963. Human growth hormone and albumin metabolism in patients with cirrhosis. Metab. Clin. Exptl. 12: 1.

38. Grossman, J., and A. A. Yalow. 1965. Effects of anabolic steroids on albumin metabolism. J. Clin. Endocrinol. Metab. 25: 698.

39. Alleyne, G. A., and V. H. Young. 1967. Adrenocortical function in children with severe protein calorie malnutrition. Clin. Sci. 33: 189.

40. Pimstone, B. L., W. Wittmann, J. D. L. Hansen, and P. Murray. 1966. Growth hormone and kwashiorkor. Lancet. 2: 779.

41. Montgomery, R. D. 1962. Urinary radio-iodine excretion in the malnourished infant. Arch. Disease Childhood. $37: 383$.

42. Hunter, W. M., and F. C. Greenwood. 1964. Studies on the secretion of human-pituitary-growth hormone. Brit. Med. J. 1: 804.

43. Dean, R. F. A., and R. Schwartz. 1953. The serum chemistry in uncomplicated kwashiorkor. Brit. J. Nutr. 7: 131.

44. Montgomery, R. D. 1963. The relation of oedema to serum protein and pseudocholinesterase levels in the malnourished infant. Arch. Disease Childhood. 38: 343.

45. Waterlow, J. C., J. Cravioto, and J. M. L. Stephen. 1960. Protein malnutrition in man. Advan. Protein Chem. 15: 131.

46. Stephen, J. M. L., and J. C. Waterlow. 1966. Use of carbon-14-labelled arginine to measure the catabolic rate of serum and liver proteins and the extent of amino-acid recycling. Nature. 211: 978.

47. Yuile, C. L., F. V. Lucas, R. D. Nubecker, C. G. Cochrane, and G. H. Whipple. 1959. Depletion of reserve protein from extravascular extracellular fluid. C 14 labeling of plasma proteins in dogs after plasmapheresis. J. Exptl. Med. 109: 165.

48. Wassermann, K., J. D. Joseph, and H. S. Mayerson. Kinetics of vascular and extravascular protein exchange in unbled and bled dogs. Am. J. Physiol. 184: 175.

49. Rothschild, M. A., M. Oratz, C. D. Evans, and S. S. Schreiber. 1966. Role of hepatic interstitial albumin in regulating albumin synthesis. Am. J. Physiol. 210: 57. 